\title{
The $\left(\mathrm{Na}^{+}, \mathrm{K}^{+}\right)$ATPase of Rat Kidney: Purification, Biosynthesis, and Processing
}

\author{
Masayuki Akayama, Hiroshi Nakada*, Koichiro Omori, Ruichi Masaki, \\ Shigeru Taketani** and Yutaka Tashiro \\ Department of Physiology, and **Department of Hygiene, Kansai Medical \\ University, Moriguchi-shi, Osaka 570, Japan
}

\begin{abstract}
Na}^{+}, \mathrm{K}^{+}\right)$ATPase was purified from rat renal outer medulla by concanavalin A- and wheat germ agglutinin-lectin Sepharose affinity chromatographies. The antibody, which was raised in rabbits, markedly inhibited ATPase activity. The monospecificity of this antibody was assayed by the Ouchterlony double immunodiffusion and Western blotting tests. The endoplasmic reticulum (ER)-rich, and Golgi-rich subfractions were prepared from the rat kidney microsomal fraction by sucrose density gradient centrifugation. On the immuoblot, the molecular weight of the $\alpha$ subunit in both fractions was 95 kilodalton (Kd); whereas, that of the $\beta$ subunit was $50 \mathrm{Kd}$ in the ER-rich fraction and $54 \mathrm{Kd}$ in the Golgi-rich fraction. When treated with endoglucosidase $\mathrm{H}$, the $50 \mathrm{Kd}$ component was converted to $38 \mathrm{Kd}$, but the $54 \mathrm{Kd}$ component was endoglucosidase $\mathrm{H}$ resistant. These results suggest that the $\beta$ subunit ( $38 \mathrm{Kd}$ ) is glycosylated cotranslationally in the ER $(50 \mathrm{Kd})$ then is converted to the mature type subunit $(54 \mathrm{Kd})$ in the Golgi apparatus.
\end{abstract}

$\left(\mathrm{Na}^{+}, \mathrm{K}^{+}\right)$ATPase is a plasma membrane protein which is composed of two noncovalently-linked subunits; a catalytic $\alpha$ subunit $(\sim 100 \mathrm{Kd})$ and a glycosylated $\beta$ subunit $(\sim 50 \mathrm{Kd})$ of unknown function $(15,17)$. This ATPase has been purified from different tissues of various animals. Of these tissues, the outer medulla of mammalian kidney is the best for this enzymes purification, as reported by $\mathrm{J} \phi$ rgensen $(12,13)$.

Else where we reported purification of the $\alpha$ and $\beta$ subunits of canine $\left(\mathrm{Na}^{+}, \mathrm{K}^{+}\right)$ ATPase from the J $\phi$ rgensen's ATPase fraction by WGA lectin-Sepharose affinity column chromatography (22). This method also has been used to purify the $\left(\mathrm{Na}^{+}\right.$, $\left.\mathrm{K}^{+}\right)$ATPase of the canine kidney outer medulla and the distribution of the ATPase on the cell surfaces of canine hepatocytes was analyzed quantitatively with monospecific antibody against the purified $\left(\mathrm{Na}^{+}, \mathrm{K}^{+}\right)$ATPase (28).

In the study reported here we used the lectin-Sepharose affinity chromatography

* Present address: Kyoto Sangyo University, Kyoto 603, Japan

Abbreviations used: $\mathrm{C}_{12} \mathrm{E}_{8}$, octaethylene glycol dodecyl ether; Con A, concanavalin A; DTT, dithiothreitol; EDTA, ethylenediamine-tetraacetic acid; endo $\mathrm{H}$, endo- $\beta$ - $\mathrm{N}$-acetylglucosaminidase $\mathrm{H}$; ER, endoplasmic reticulum; IgG, immunoglobulin G; Kd, Kilo dalton; Pi, inorganic phosphate; PMSF, phenylmethylsulfonyl fluoride; SDS-PAGE, sodium dodecyl sulfate-polyacrylamide gel electrophoresis; WGA, wheat germ agglutinin. 
to purify the $\left(\mathrm{Na}^{+}, \mathrm{K}^{+}\right)$ATPase from the outer medulla of rat kidney and prepared the monospecific antibody against this enzyme. Using antibody, we investigated biosynthesis and processing of the ATPase of rat kidney.

This research was presented, in part, at the 63rd Annual Meeting of the Physiological Society of Japan (1).

\section{MATERIALS AND METHODS}

Materials. Trasylol was purchased from Bayer. Leupeptin and pepstatin were obtained from the Protein Research Foundation (Osaka, Japan). Con A-Sepharose 4B and WGASepharose $6 \mathrm{MB}$ were the products of Pharmacia Fine Chemicals. Endo glycosidase $\mathrm{H}$ (Endo H) was purchased from Seikagaku Kogyo Co., Tokyo. ${ }^{125}$ I-protein A was obtained from New England Nuclear. Nitrocellulose sheets (HAWP 304 FO) were purchased from Millipore Corporation. All the other chemicals used were of analytical grade and were obtained from various sources.

Animals. Male Sprague-Dawley rats weighing about $150 \mathrm{~g}$ were used. They were fed a commercial chow and water ad libitum.

Preparation of crude $\left(\mathrm{Na}^{+}, \mathrm{K}^{+}\right)$ATPase from rat kidney. Microsomal membranes were prepared from the outer medulla of rat kidneys by a slight modification of J $\phi$ rgensen's procedure $(22)$ described previously $(12,13)$ : The tissues were homogenized in $0.25 \mathrm{M}$ sucrose containing $30 \mathrm{mM}$ histidine buffer (pH 7.2), 1 mM EDTA, $1 \mathrm{mM}$ PMSF, $200 \mathrm{U} / \mathrm{ml}$ trasyol, $20 \mu \mathrm{g} / \mathrm{ml}$ leupeptin and $20 \mu \mathrm{g} / \mathrm{ml}$ pepstatin. The microsomal fraction $(1.4 \mathrm{mg}$ protein $/ \mathrm{ml}$ ) was sedimented by the centrifugation at $48,000 \mathrm{x}$ g for $30 \mathrm{~min}$ then treated with SDS $(0.54 \mathrm{mg} / \mathrm{ml})$ at $20^{\circ} \mathrm{C}$ for $45 \mathrm{~min}$ in $50 \mathrm{mM}$ imidazole buffer (pH 7.5) containing $2 \mathrm{mM}$ EDTA, $3 \mathrm{mM}$ ATP, $1 \mathrm{mM}$ DTT, $200 \mathrm{U} / \mathrm{ml}$ trasylol, $20 \mu \mathrm{g} / \mathrm{ml}$ leupeptin and $20 \mu \mathrm{g} / \mathrm{ml}$ pepstatin.

The treated fraction was layered on a discontinuous sucrose density gradient that consisted of three layers; $25 \mathrm{ml}$ of $29.4 \%, 15 \mathrm{ml}$ of $15 \%$, and $25 \mathrm{ml}$ of $10 \%(\mathrm{~W} / \mathrm{V})$ sucrosein $25 \mathrm{mM}$ in $25 \mathrm{mM}$ imidazole buffer ( $\mathrm{pH} 7.5$ at $20^{\circ} \mathrm{C}$ ) containing $1 \mathrm{mM}$ EDTA. This gradient then was centrifuged in a Hitachi RP 42 rotor at $137,500 \times \mathrm{g}$ for $5 \mathrm{~h}$ at $4^{\circ} \mathrm{C}$. The pellets obtained were resuspended at a concentration of $2-3 \mathrm{mg}$ protein $/ \mathrm{ml}$ in $50 \mathrm{mM}$ sodium acetate buffer (pH 5.6) containing $1 \mathrm{mM}$ EDTA. This suspension was diluted to a final concentration of $0.2-0.3 \mathrm{mg}$ protein $/ \mathrm{ml}$ by 9-fold dilution with $50 \mathrm{mM}$ imidazole buffer ( $\mathrm{pH} 7.5$ ) containing $1 \mathrm{mM}$ EDTA. The specific activity of this crude ATPase fraction was $700-800 \mu$ moles $\mathrm{Pi}$ released $/ \mathrm{mg} / \mathrm{h}$.

Purification of $\left(\mathrm{Na}^{+}, \mathrm{K}^{+}\right)$ATPase by Con A- and WGA-Sepharose affinity chromatography. $\mathrm{J} \phi$ rgensen's ATPase fraction was treated with $\mathrm{C}_{12} \mathrm{E}_{8}(4,10,21,28)$ and subjected to Con A-Sepharose 4B affinity chromatography followed by WGA-Sepharose 6 MB chromatography as reported previously (28): $10 \% \mathrm{C}_{12} \mathrm{E}_{8}$ solution was added to $3 \mathrm{ml}$ of the $\mathrm{J} \phi$ rgensen's $\left(\mathrm{Na}^{+}, \mathrm{K}^{+}\right)$ATPase fraction $(2 \mathrm{mg}$ protein $/ \mathrm{ml}$ ) containing $200 \mathrm{U} / \mathrm{ml}$ trasylol, $20 \mu \mathrm{g} / \mathrm{ml}$ leupeptin and $20 \mu \mathrm{g} / \mathrm{ml}$ pepstatin, at a weight ratio of protein to $\mathrm{C}_{12} \mathrm{E}_{8}$ of $1: 10$ (final concentration of $\left.\mathrm{C}_{12} \mathrm{E}_{8}, 20 \mathrm{mg} / \mathrm{ml}\right)$. Solubility of the $\left(\mathrm{Na}^{+}, \mathrm{K}^{+}\right)$ATPase at this concentration of $\mathrm{C}_{12} \mathrm{E}_{8}$ was greater than at the previous concentration $(1: 3)$, but ATPase activity was almost completely lost. The mixture was incubated at $0^{\circ} \mathrm{C}$ for $1 \mathrm{~h}$ then centrifuged at $100,000 \times \mathrm{g}$ for $1 \mathrm{~h}$.

The supernatant formed was dialyzed at $4^{\circ} \mathrm{C}$ for $3 \mathrm{~h}$ against $10 \mathrm{mM}$ Tris/ $\mathrm{HCl}$ buffer (pH 7.5) containing $0.15 \mathrm{M} \mathrm{NaCl}$ and $0.01 \% \mathrm{C}_{12} \mathrm{E}_{8}$. The dialyzed solution was incubated at $4{ }^{\circ} \mathrm{C}$ overnight with Con A-Sepharose previously equibrated with $10 \mathrm{~m} \mathrm{M}$ Tris/ $\mathrm{HCl}$ buffer 
(pH 7.5), containing $0.15 \mathrm{M} \mathrm{NaCl}$ and $0.01 \% \mathrm{C}_{12} \mathrm{E}_{8}$, then it was centrifuged. Its supernatant was loaded on a WGA-Sepharose column $(0.5 \times 5 \mathrm{~cm})$ that had been equilibrated with the same buffer. The fraction that bound to the WGA-Sepharose was eluted with $0.2 \mathrm{M} \mathrm{N}$ acetylglycosamine after washing the column with 10 column volumes of the equilibration buffer.

Antibody preparation. Purified $\left(\mathrm{Na}^{+}, \mathrm{K}^{+}\right)$ATPase in Freund's complete adjuvant was injected subcutaneously into rabbits $(\sim 200 \mu \mathrm{g}$ protein/animal $)$ at $30-40$ sites; then, 3 and 6 weeks later the ATPase in Freund's incomplete adjuvant was injected the same way according to the method of Vaitukaitis (30). Nine weeks later, $100 \mu \mathrm{g}$ of the ATPase was given as a boostered. The IgG fraction was obtained by ammonium sulfate fractionation and DEAE cellulose (DE 52) column chromatography.

Inhibition of rat kidney $\left(\mathrm{Na}^{+}, \mathrm{K}^{+}\right)$ATPase activity by the antibody. As described elsewhere (22), 0-200 $\mu 1$ of antiserum or non-immunized rabbit serum, which previously had been dialyzed extensively against water, and $10 \mu \mathrm{l}$ of $\mathrm{J} \phi$ rgensen's $\left(\mathrm{Na}^{+}, \mathrm{K}^{+}\right) \mathrm{ATPase}$ fraction $(0.4 \mathrm{mg} / \mathrm{ml})$ were added to $10: 9$ concentrated buffer $(3 \mathrm{mM} \mathrm{MgCl}, 130 \mathrm{mM} \mathrm{NaCl}, 20 \mathrm{mM}$ $\mathrm{KCl}, 30 \mathrm{mM}$ histidine, $\mathrm{pH} 7.5$ ) with or without $1 \mathrm{mM}$ ouabain at a final volume of $0.45 \mathrm{ml}$. This mixture was incubated at $37^{\circ} \mathrm{C}$ for $20 \mathrm{~min}$, after which $50 \mu 1$ of $30 \mathrm{mM}$ ATP was added. After another $5 \mathrm{~min}$, the reaction was stopped by adding $50 \mu \mathrm{l}$ of $50 \%$ trichloroacetic acid and cooling the sample to $0^{\circ} \mathrm{C}$. The amount of Pi released was determined by the method of Pavin and Roberts (23).

Subfractionation of the microsomes. The microsomal fraction prepared by the method of $\mathrm{J} \phi$ rgensen $(12,13)$ was resuspended in $0.25 \mathrm{M}$ sucrose containing $50 \mathrm{mM}$ histidine buffer (pH 7.2) to a final volume of $2 \mathrm{ml}$ ( $\sim 10 \mathrm{mg}$ protein). This suspension was loaded on a continuous sucrose density gradient of $0.8 \mathrm{M}-1.4 \mathrm{M}$ sucrose containing $50 \mathrm{mM}$ imidazole buffer, $\mathrm{pH}$ 7.5. The gradient was centrifuged at $199,000 \mathrm{x}$ g for $4 \mathrm{~h}$ in a Hitachi RPS $40 \mathrm{~T}$ rotor then was fractionated with a gradient fractionator by the continuous collection of 25 drops per tube from the top of the gradient. The fractionated samples were diluted with $0.25 \mathrm{M}$ sucrose solution, recentrifuged at $105,000 \mathrm{x}$ g for $1 \mathrm{~h}$ then resuspended in $0.5 \mathrm{ml}$ of $50 \mathrm{mM}$ histidine buffer ( $\mathrm{pH}$ 7.2). The various enzyme activities of the samples were assayed, after which a part of each was put through Western blotting analysis according to Burnette (2).

Endo $H$ treatment of the cell subfractions. The subfractions were dialyzed at $4{ }^{\circ} \mathrm{C}$ overnight against $0.1 \mathrm{M}$ sodium citrate buffer ( $\mathrm{pH} 5.5$ ) containing $1 \mathrm{mM}$ PMSF, $200 \mathrm{U} / \mathrm{ml}$ trasylol, $20 \mu \mathrm{g} / \mathrm{ml}$ leupeptin and $20 \mu \mathrm{g} / \mathrm{ml}$ pepstatin, after which they were treated with $0.05 \mathrm{U}$ of endo $\mathrm{H}$ at $37^{\circ} \mathrm{C}$ for $24 \mathrm{~h}$ in $0.1 \mathrm{M}$ sodium citrate buffer ( $\mathrm{pH} 5.5$ ), containing $0.5 \mathrm{mM}$ PMSF, $0.04 \%$ sodium azide and $0.2 \%$ SDS. Next, the solution was adjusted to $\mathrm{pH} 6.8$ by adding $1 \mathrm{M}$ Tris/ $\mathrm{HCl}$ buffer ( $\mathrm{pH} \mathrm{8.0)}$ diluted with an equal volume of the SDS-PAGE sample buffer containing $2 \%$ SDS, $20 \mathrm{mM}$ phosphate buffer (pH 7.0), $8 \mathrm{M}$ urea, $4 \%$ 2-mercaptoethanol and $20 \%$ glycerol. The samples were heated at $100^{\circ} \mathrm{C}$ for $5 \mathrm{~min}$ then subjected to SDS-PAGE.

Cell-free translation of poly(A)-containing $m R N A$ from rat kidney. Poly(A)-containing mRNA was isolated from rat kidney according to Geregori et al. (9) and translated in a rabbit reticulocyte lysate system as described in the legend to Fig. 8.

Other procedures. Amino acid analysis of the $a$ and $\beta$ subunits was done with a LKB amino acid analyser (Model 4,000). Protein was determined by the method of Lowry et al. (20) with crystallized bovine serum albumin as the standard. SDS-PAGE was done with a $10 \%$ polyacrylamide gel according to the method of Laemmli (18). Glucose-6-phosphatase was determined by the procedure of Leskes et al. (19), galactosyltransferase by that of Fleischer et al. (7), 5'-nucleotidase by that of Emmelot et al. (3), and acid phosphatase by 
that of Pricer and Ashwell (24).

\section{RESULTS}

Purification of $\left(\mathrm{Na}^{+}, \mathrm{K}^{+}\right)$ATPase. Crude $\left(\mathrm{Na}^{+}, \mathrm{K}^{+}\right)$ATPase was prepared from the outer medulla by SDS treatment and sucrose density gradient centrifugation according to a slight modification of J $\phi$ rgensen's procedure. The specific activity of this ATPase fraction ranged from $600-800 \mu$ mole of $\mathrm{Pi}$ released $/ \mathrm{mg} / \mathrm{h}$, and the apparent molecular weights of the $\alpha$ and $\beta$ subunits were $95 \mathrm{Kd}$, and $54 \mathrm{Kd}$. This preparation, however, contained several impurifies (Fig. 1, lane 1, small arrows) as reported previously (28). The $\left(\mathrm{Na}^{+}, \mathrm{K}^{+}\right)$ATPase from this fraction was further purified by treating it with $\mathrm{C}_{12} \mathrm{E}_{8}$ followed by Con A- and WGA-Sepharose affinity chromatographies.

Treatment of the crude enzyme with $2 \% \mathrm{C}_{12} \mathrm{E}_{8}$ solution was very effective making this enzyme soluble as reported previously (28), and the component which migrated more rapidly than the $\beta$ subunit (Fig. 1. lane 1, lower arrow), was removed by this procedure; but, $\left(\mathrm{Na}^{+}, \mathrm{K}^{+}\right)$ATPase activity was lost. The band which migrated more slowly than the a subunit (Fig. 1, lane 1, upper arrow) was effectively removed by treatment with Con A-Sepharose.

The final purification of the rat kidney $\left(\mathrm{Na}^{+}, \mathrm{K}^{+}\right)$ATPase was made by WGASepharose chromatography as described by Takemura et al. (28). Our purified ATPase was exclusively composed of $\alpha$ and $\beta$ subunits with the apparant molecular weights of $95 \mathrm{Kd}$ and $54 \mathrm{Kd}$ (Fig. 1, lane 2). The specific activity during the purification procedures was not shown, because ATPase activity had been lost when the J $\phi$ rgensen's ATPase fraction was treated with $\mathrm{C}_{12} \mathrm{E}_{8}$. The yield of protein was $6.3 \pm 2.1 \%(n=6)$, that of J $\phi$ rgensen's ATPase fraction.

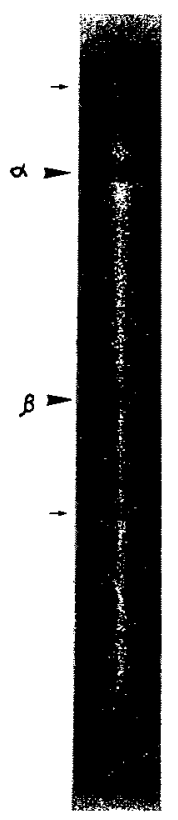

1

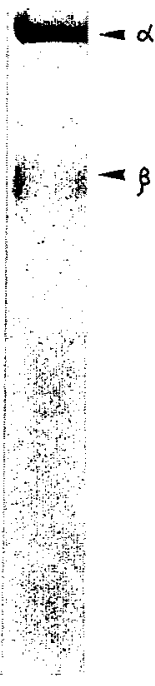

2
Fig. 1. SDS-PAGE patterns of rat kidney $\left(\mathrm{Na}^{+}, \mathrm{K}^{+}\right)$ATPase preparations. The $\left(\mathrm{Na}^{+}, \mathrm{K}^{+}\right)$ATPase fraction prepared by SDS treatment $(0.54 \mathrm{mg} / \mathrm{ml})$ according to the method of J $\phi$ rgensen (12, 13) was dissolved in $2 \% \mathrm{C}_{12} \mathrm{E}_{8}$ solution then centrifuged. The supernatant was chromatographed on a Con A-Sepharose column then on a WGA-Sepharose column.

Lane 1: SDS-treated rat kidney $\left(\mathrm{Na}^{+}, \mathrm{K}^{+}\right)$ATPase fraction.

Lane 2: WGA-Sepharose-bound fraction eluted with $0.2 \mathrm{M} \mathrm{N}$ acetylglucosamine. 
Amino acid composition of the subunits. The $\alpha$ and $\beta$ subunits resolved by SDSPAGE were extracted separately from the gel, pooled, and their amino acids analyzed. Table I shows the amino acid compositions of the $a$ and $\beta$ subunits of rat kidney $\left(\mathrm{Na}^{+}, \mathrm{K}^{+}\right)$ATPase together with those of the canine kidney ATPase previously

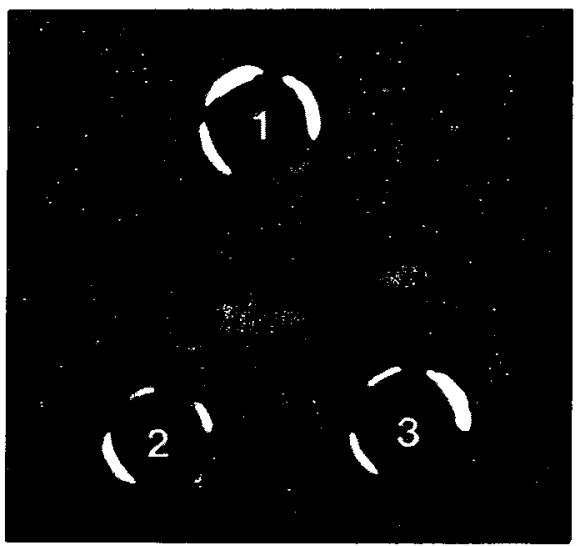

Fig. 2. Ouchterlony double immunodiffusion analysis of the purified rat kidney $\left(\mathrm{Na}^{+}, \mathrm{K}^{+}\right) \mathrm{ATPase}$. The enzymes was analysed in $1 \%$ agarose containing $0.1 \%$ Triton $\mathrm{X}-100,10 \mathrm{mM}$ soduim phosphate buffer (pH 7.2), 0.15 M NaCl, 0.02\% NaN3. Well 1; anti(Na+, $\left.\mathrm{K}^{+}\right)$ATPase antibody, Well 2, 3; purified $\left(\mathrm{Na}^{+}, \mathrm{K}^{+}\right)$ATPase.

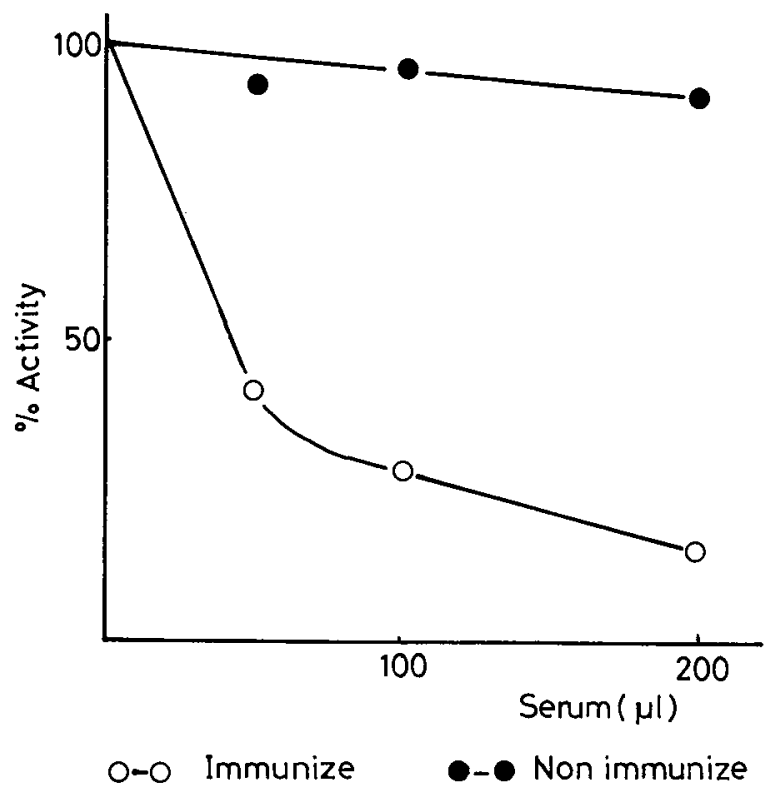

Fig. 3. Inhibition of rat kidney $\left(\mathrm{Na}^{+}, \mathrm{K}^{+}\right)$ATPase activity by rabbit antibody against rat $\left(\mathrm{Na}^{+}\right.$, $\mathrm{K}^{+}$)ATPase. The J $\phi$ rgensen's $\left(\mathrm{Na}^{+}, \mathrm{K}^{+}\right)$ATPase fraction prepared from rat kidney first was incubated with various amounts of nonimmunized rabbit serum (O) or antiserum $(O)$ in the presence or absence of $1 \mathrm{mM}$ ouabain at $37^{\circ} \mathrm{C}$ for 20 min then incubated with ATP. The amount of Pi liberated was measured as described in Materials AND METHODs. An addition of $200 \mu \mathrm{l}$ of antiserum markedly inhibited enzyme activity ( $85 \%$ inhibition). 
reported from this laboratory (22). Our present results are in general agreement with those for canine kidney ATPase.

Antibody specificity shown by the Ouchterlony test, inhibition assay and Western blot. The antibody against purified $\left(\mathrm{Na}^{+}, \mathrm{K}^{+}\right)$ATPase was raised in rabbits. It formed a single precipitation line with the purified antigen on Ouchterlony double immunodiffusion analysis (Fig. 2). Similar result was obtained with the microsomal membranes in the presence of $0.1 \%$ Triton X-100. We then examined the inhibition of kidney $\left(\mathrm{Na}^{+}, \mathrm{K}^{+}\right)$ATPase by this antibody. Fig. 3 shows that the antiserum effectively inhibited this enzymes activity.

The specificity of the antibody also was tested by Western blotting analysis. In Fig. 4, lanes 1 and 2 show SDS-PAGE patterns (10\% polyacrylamide gel) of the original and the SDS treated-microsomal fractions. Lanes 3 and 4 are immunoblots of the same samples. In the latter two fractions, the antibody bound exclusively with two components that correspond to the $\alpha(95 \mathrm{Kd})$ and $\beta(54 \mathrm{Kd})$ subunits. The upper band (arrow) above the $\alpha$ subunit presumably represent $1: 1$ complex of $\alpha$ and $\beta$ subunits.

Subfractionation studies. In vivo processing of the $\alpha$ and $\beta$ subunits was investigated with this monospecific antibody against the enzyme. The microsomal fraction prepared from the outer medulla of rat kidney was subfractionated by sucrose

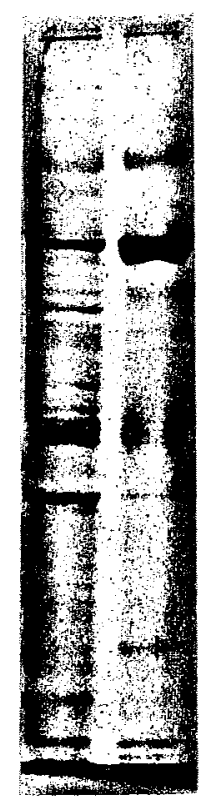

12
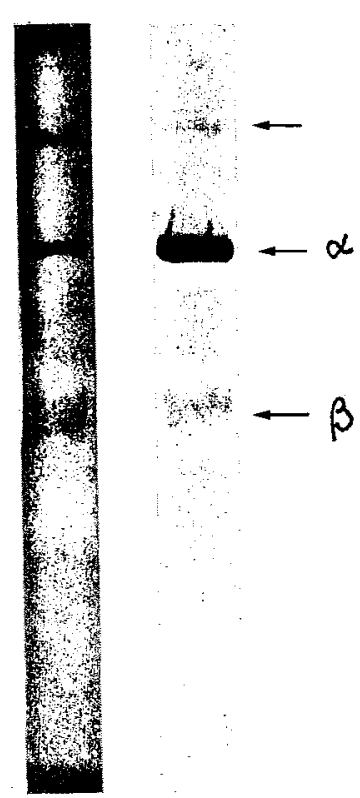

3

\section{4}

Fig. 4. Characterization of the antibody by immunoblotting. Lanes 1, 2: SDS-PAGE patterns of the microsomal fraction (lane 1) (50 $\mu$ g protein) and the J $\phi$ rgensen's crude $\left(\mathrm{Na}^{+}, \mathrm{K}^{+}\right)$ATPase fraction (lane 2) (20 $\mathrm{g}$ g protein).

Lanes 3, 4: Protein from lanes 1 and 2 was transferred electrophoretically to a nitrocellulose sheet by the method of Burnette (14). The sheet was allowed to react with the antibody solution $(0.1 \mathrm{mg} / \mathrm{ml}$ in $50 \mathrm{mM}$ Tris/ $\mathrm{HCl}$ buffer, $\mathrm{pH} 7.6$, containing $0.9 \% \mathrm{NaCl}, 0.05 \% \mathrm{NaN}_{3}$, and $5 \%$ bovine serum albumin). It then was incubated with ${ }^{125} \mathrm{I}$-protein $\mathrm{A}$, after which it was checked by autoradiography. 
density gradient centrifugation. The submicrosomal fractions collected were characterized by assays with several marker enzymes, after which they were analyzed by Western blotting.

The specific activities of glucose-6-phosphatase, galactosyltransferase, 5'nucleotidase and acid phosphatase used as the respective marker enzymes of the ER, Golgi apparatus, plasma membrane and lysosomes, are shown in Fig. 5.

Most of the galactosyl transferase activity was mostly concentrated in fraction 3 and showed a marked decrease in the direction of both the lighter and heavier fractions, whereas, glucose-6-phosphatase activity had a bimodal distribution, the higher peak occurring in fraction 8 and the other peak in fraction 4 . The acid-phosphatase activity was greatest in fraction 7, whereas the activity of 5'-nucleotidase was spread over all the fractions and showed no peaks. Number 3 is the Golgi-rich and number 8 the ER-rich fractions.

Western blot analysis of the subfractions. Lane 1 of Fig. 6 shows the immunoblot of fraction 8 (ER-rich) and lane 2 that of fraction 3 (Golgi-rich). In the Golgi-rich fraction, the antibody bound with the $95 \mathrm{Kd}$ and $54 \mathrm{Kd}$ components, whereas, in the ER-rich fraction it bound mainly with the $95 \mathrm{Kd}$ and $50 \mathrm{Kd}$ components. In the

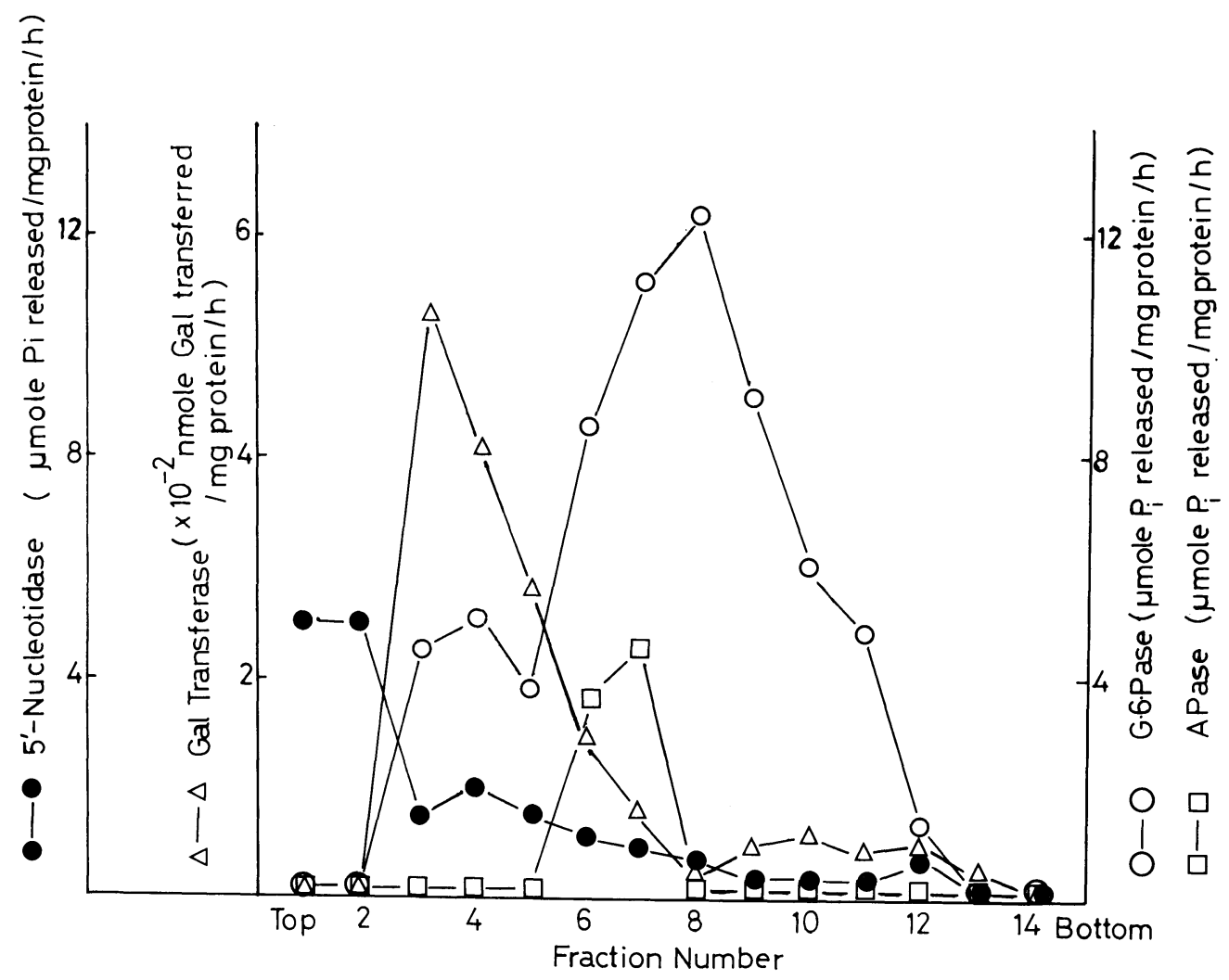

Fig. 5. Subfractionation of rat kidney microsomes by sucrose density gradient centrifugation. The microsomes ( $\sim 10 \mathrm{mg}$ protein) were centrifuged for $4 \mathrm{~h}$ at $199,000 \mathrm{x} \mathrm{g}$ on a $0.8-1.4 \mathrm{M}$ linear sucrose gradient then fractionated. The subfractions obtained were pelleted and resuspended $(0.5 \mathrm{ml}$ each) assayed as described in MATERIALS AND Methods. 


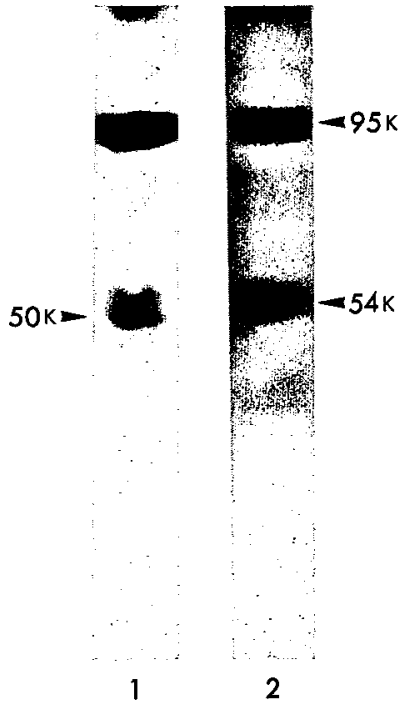

Fig. 6. Western blotting the Golgi-rich and ER-rich fractions. Fraction 3 (lane 2) has the highest galactosyltransferase activity and fraction 8 (lane 1) the highest glucose-6-phosphatase activity. They were designated the Golgi-rich and ER-rich subfrantions. These two fractions were assayed by SDS-PAGE followed by immunoblotting and autoradiography.

latter fraction, a small amount of the $54 \mathrm{Kd}$ component also was detected.

These findings suggest that, whereas the molecular weight of the $\alpha$ subunit did not change in the two subfractions, the $\beta$ subunit that first was synthesized as a $50 \mathrm{Kd}$ glycoprotein in the ER was converted to a mature $54 \mathrm{Kd}$ form in the Golgi apparatus. A small amount of the $54 \mathrm{Kd}$ component in the Golgi rich fraction is presumably to be due to contamination of the Golgi or post Golgi membranes.

Endo $H$ treatment of the ER-rich and Golgi-rich subfractions. We examined whether the $50 \mathrm{Kd}$ form of the $\beta$ subunit in the ER-rich fraction (Fraction 8) contains highmannose oligosaccharides of the $\mathrm{N}$-glycoside type. We used endo $\mathrm{H}$ to digest both the ER-rich and Golgi-rich subfractions then analyzed the digests by SDS-PAGE and Western blotting.

The $\beta$ subunit ( $50 \mathrm{Kd}$ ) in the ER-rich subfraction was sensitive to endo $\mathrm{H}$ and was converted to a $38 \mathrm{Kd}$ form (Fig. 7); whereas the $\beta$ subunit ( $54 \mathrm{Kd}$ ) in the Golgi-rich subfraction was resistant to endo $\mathrm{H}$ (data not shown).

The difference in the amount of the $\alpha$ subunits present before and after endo $\mathrm{H}$ digestion (Fig. 7) is presumed to be due to proteolytic cleavage during this endo $\mathbf{H}$ digestion the $a$ subunit being much more sensitive to protease digestion than the $\beta$ subunit (22). This protease activity was most probably derived from the endo $\mathrm{H}$ preparation, which were not inhibited by any protease inhibitors commercially available.

Cell-free translation of poly(A)-containing $m R N A$ from rat kidney. Poly(A)containing mRNA was prepared from rat kidney and translated in a rabbit reticulocyte cell-free system. The products were immunoprecipitated with the antibody against $\left(\mathrm{Na}^{+}, \mathrm{K}^{+}\right)$ATPase or the control immunoglobulin from non-immunized rabbit serum then subjected to SDS-PAGE. A comparison of lanes 1 and 3 of Fig.8, shows that the antibody against $\left(\mathrm{Na}^{+}, \mathrm{K}^{+}\right)$ATPase immunoprecipitated a $38 \mathrm{Kd}$ component in lane 1 (arrow head). This cell-free translation system, however, did not show the $\sim 100 \mathrm{Kd}$ component which corresponds to the $\alpha$ subunit of the ATPase. Presumably the $a$ subunit was degraded during cell-free translation because it is 


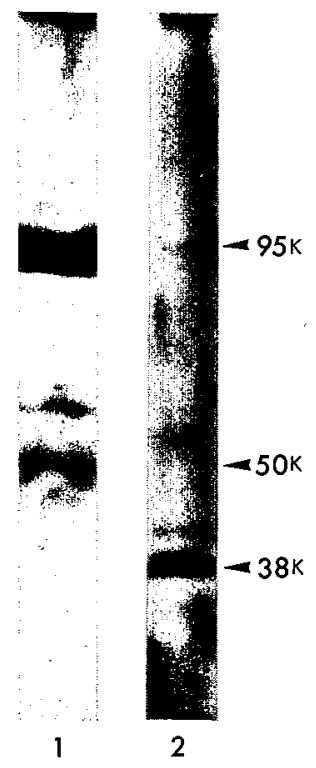

Fig. 7. Endo $H$ sensitivity of the ER-rich subfraction. The ER-rich subfraction $(\sim 50 \mu$ g protein) was treated without (lane 1), or with (lane 2$)$, $0.05 \mathrm{U}$ of endo $\mathrm{H}$ as described in Materials AND METHODs. after which it was assayed by SDS-PAGE followed by immunoblotting and autoradiography.

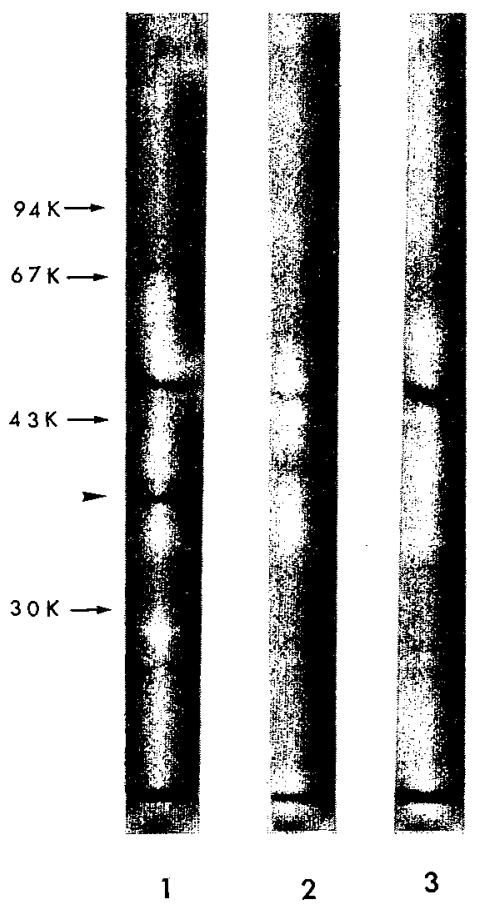

Fig. 8. Cell-free translation of poly(A)-containing mRNA from rat kidney. Poly(A)-containing mRNA was translated in vitro $\left(0.08\right.$ or $\left.0.24 \mathrm{~A}_{260} / 50 \mu \mathrm{l}\right)$ in a reticulocyte lysate containing $\left({ }^{35} \mathrm{~S}\right)$ methionine $(50 \mu \mathrm{Ci})$. After incubation for $60 \mathrm{~min}$ at $30^{\circ} \mathrm{C}$, the translation mixtures were cooled on ice then diluted ten-fold with the lysate buffer (containing $1 \%$ Triton X 100, $0.1 \%$ SDS, $10 \mathrm{mM}$ Tris- $\mathrm{HCl}$ buffer, $\mathrm{pH}$ 7.3, $0.2 \mathrm{M} \mathrm{NaCl}$, and $5 \mathrm{mM}$ EDTA). After the additions of $0.1 \mathrm{mM}$ PMSF and $1 \mathrm{mM}$ dithiothreitol, the mixtures were incubated at $4^{\circ} \mathrm{C}$ for $1 \mathrm{~h}$ with Staphyloccocus Aureus then centrifuged. The supernatants obtained were allowed to react with antiserum against rat $\left(\mathrm{Na}^{+}, \mathrm{K}^{+}\right)$ATPase (lane 1) or with normal rabbit serum (lane 3 ) for $1 \mathrm{~h}$ at room temparature, then to react with $50 \mu$ l of protein $\mathrm{A}(50 \%$ in PBS), followed by stirring for $1 \mathrm{~h}$ at $4^{\circ} \mathrm{C}$. After washing the precipitated proteins with the above buffer, they were dissolved in 1 $\%$ SDS, $10 \mathrm{mM}$ sodium phosphate buffer (pH 7.0), 10\% glycerol, $4 \mathrm{M}$ urea and $2 \%$ mercaptoethanol, after which they were heated for $5 \mathrm{~min}$ at $100^{\circ} \mathrm{C}$ then assayed by SDS-PAGE followed by fluorography. Lane 2 showed that the immunoprecipitated component with the antibody (lane 1) could be immunocompeted by the addition of the $\beta$ subunit $(100 \mu \mathrm{g})$. The arrowhead indicates the translation product with an apparent molecular mass of $\sim 38 \mathrm{Kd}$ which corresponds to the core polypeptide of the $\beta$ subunit.

much more sensitive to protease digestion than is the $\beta$ subunit.

\section{DISCUSSION}

$\left(\mathrm{Na}^{+}, \mathrm{K}^{+}\right)$ATPase has been prepared from a variety of tissues from different 
TABLE I. AMINO ACID CONPOSITION OF THE $\alpha$ AND $\beta$ SUBUNITS OF RAT KIDNEY $\left(\mathrm{Na}^{+}, \mathrm{K}^{+}\right)$

ATPASE. VAlues GIVEN IN MOL PER 100 MOL AMINO ACIDS

\begin{tabular}{|c|c|c|c|c|}
\hline & \multicolumn{2}{|c|}{$a$ subunit } & \multicolumn{2}{|c|}{$\beta$ subunit } \\
\hline & Rat Kidney & Dog Kidney* & Rat Kidney & Dog Kidney* \\
\hline Aspartic acid & 8.8 & 11.0 & 9.2 & 9.3 \\
\hline Threonine & 5.4 & 6.3 & 4.9 & 3.8 \\
\hline Serine & 6.7 & 5.8 & 6.0 & 4.5 \\
\hline Glutamic acid & 11.6 & 11.5 & 11.6 & 13.5 \\
\hline Proline & 7.4 & 5.0 & 6.3 & 6.4 \\
\hline Glycine & 9.9 & 8.1 & 11.5 & 9.4 \\
\hline Alanine & 7.1 & 8.9 & 6.0 & 3.2 \\
\hline Half-cystine & 0.5 & 1.3 & 1.7 & 1.2 \\
\hline Valine & 6.9 & 6.4 & 5.4 & 5.2 \\
\hline Methionine & 1.9 & 1.7 & 1.4 & 1.4 \\
\hline Isoleucine & 5.6 & 6.2 & 4.6 & 5.9 \\
\hline Leucine & 8.1 & 9.0 & 8.9 & 7.7 \\
\hline Tyrosone & 3.0 & 2.5 & 2.9 & 6.3 \\
\hline Phenylalanine & 4.3 & 4.1 & 6.7 & 5.3 \\
\hline Lysine & 4.3 & 5.2 & 5.9 & 9.6 \\
\hline Histidine & 1.21 & 1.5 & 1.6 & 0.1 \\
\hline Tryptophan & - & 0.7 & - & 1.3 \\
\hline Arginine & 6.4 & 5.1 & 4.1 & 5.9 \\
\hline
\end{tabular}

Data of Omori et al. (21).

animals. Of the mammalian tissues, kidney has provided the only sources of pure $\left(\mathrm{Na}^{+}, \mathrm{K}^{+}\right)$ATPase (14), $\left(\mathrm{Na}^{+}, \mathrm{K}^{+}\right)$ATPase having been prepared from the kidneys of various mammalians including the rat $(16,26,27)$.

In a previous paper, we showed that $\mathbf{J} \phi$ rgensen's $\left(\mathrm{Na}^{+}, \mathrm{K}^{+}\right)$ATPase fraction prepared from canine kidneys contained impurities (28). We therefore further purified the ATPase from this fraction using the selective solubility of this enzyme in $\mathrm{C}_{12} \mathrm{E}_{8}$ then lectin-Sepharose chromatography (28).

As with canine kidney, the fraction from rat kidney contained impurities which could be eliminated by selective solubility of the enzyme in $\mathrm{C}_{12} \mathrm{E}_{8}$ and by lectinSepharose chromatography (Fig. 1). The purified enzyme is composed exclusively of $\alpha$ and $\beta$ subunits with apparent molecular weights of 95 and $54 \mathrm{Kd}$. No other impurities were detected in SDS-PAGE analysis. We then prepared the antibody against the purified $\left(\mathrm{Na}^{+}, \mathrm{K}^{+}\right)$ATPase. This antibody was shown to be specific by double diffusion and immunoblot analyses and it markedly inhibited $\left(\mathrm{Na}^{+}, \mathrm{K}^{+}\right)$ ATPase activity.

Biosynthesis of $\left(\mathrm{Na}^{+}, \mathrm{K}^{+}\right)$ATPase has been studied exclusively in cultured cells such as MDCK cells (25), amphibian cells (8), chicken myogenic cells and sensory neurons $(5,29)$. We now have reported on the biosynthesis and processing of the $\alpha$ and $\beta$ subunits of $\left(\mathrm{Na}^{+}, \mathrm{K}^{+}\right)$ATPase in rat kidney in vivo.

Considerable difference exist in previous results obtained from studies of the biosynthesis of the a subunits. Sabatini et al. (25) reported that the $a$ subunit is synthesized by free polysomes and inserted post-translationally into membranes. Hiatt et al. reported finding a $96 \mathrm{Kd}$-product obtained by cell-free translation of the 
mRNA from free polysomes (29). Geering et al. (8) investigated these problems and suggested that both the $a$ and $\beta$ subunits of $\left(\mathrm{Na}^{+}, \mathrm{K}^{+}\right)$ATPase are integrated cotranslationally into the ER membrane, probably with different time courses. Tamkun and Fambrough (29) investigated the biosynthesis and intracellular transport of the $\left(\mathrm{Na}^{+}, \mathrm{K}^{+}\right)$ATPase of chick sensory neurons in culture. They suggested that $a$ and $\beta$ subunit syntheses are concurrent in the rough ER and that subunit assembly takes place during, or immediately after, polypeptide synthesis.

In the experiment reported here the molecular weights of the a subunit in both the ER-rich and Golgi-rich fractions were the same $(95 \mathrm{Kd})$, and endo $\mathrm{H}$ treatment did not change the mobility of the $\alpha$ subunit in the ER-rich fraction. We previously showed (22) that the carbohydrate content of the $\alpha$ subunit is negligible. These results are strong evidence that the $\alpha$ subunit is transported from the ER to the Golgi apparatus without glycosylation. This conclusion agrees with reports that the treatment of cultured cells with tunicamycin produced no change in the size of the $\alpha$ subunit $(5,8,25,29)$ and that the mobility of the $\alpha$ subunit of rat kidney $\left(\mathrm{Na}^{+}, \mathrm{K}^{+}\right)$ATPase was not changed by treatment with neuraminidase or endoglycosidase $F$ (27).

We found that the molecular weight of the $\beta$ subunit was $50 \mathrm{Kd}$ in the ER-rich fraction and $54 \mathrm{Kd}$ in the Golgi-rich fraction. Endo $\mathrm{H}$ treatment, did not change the molecular weight of the $\beta$ subunit in the Golgi-rich fraction, but in the ER-rich fraction it decreased from 50 to $38 \mathrm{Kd}$. The major polypeptide chains synthesized by cell-free translation of poly(A)-containing mRNA was $38 \mathrm{Kd}$, which suggests that the core polypeptide of the $\beta$ subunit, with a molecular weight of $\sim 38 \mathrm{Kd}$ is glycosylated cotranslationally in the ER to a high mannose glycoprotein of $\sim 50 \mathrm{Kd}$, after which it is transported and converted to the mature complex type $(54 \mathrm{Kd})$ in the Golgi region.

In previous research, we found the carbohydrate content of the canine $\beta$ subunit to be $33 \%$ (22). The core polypeptide of the $\beta$ subunit therefore is thus estimated as $\sim 38 \mathrm{Kd}$. This value agrees with the molecular weight of the endo $\mathrm{H}$-treated rat $\beta$ subunit $(38 \mathrm{Kd})$ and that of the product $(38 \mathrm{Kd})$ of the cell-free translation system. These results on the processing of the $\beta$ subunit also are consistent with results recently reported by Tamkun and Fambrough for cultured cells and for an in vitro translation system (29).

Acknowledgements. We thank Miss K. Miki for her assistance with the manuscript. This research was supported by a Grant-in-Aid for Scientific Research and for Special Project Research from the Ministry of Education, Science and Culture, Japan, and by grants from the Nissan Science Foundation.

\section{REFERENCES}

1. Akayama, M., A. Yamamoto, H. Nakada, R. Masaki, K. Omori, and Y. Tashiro. Biosynthesis, processing and localization of $\left(\mathrm{Na}^{+}, \mathrm{K}^{+}\right)$ATPase in rat kidney. J. Physiol. Soc. Japan 48, 1741986

2. BURnetTe, W.N. "Western blotting" electrophoretic transfer of proteins from sodium dodecyl sulfate-poly-acrylamide to unmodified nitrocellulose and radiographic detection with antibody and radio iodinated protein-A. Anal. Biochem. 112, 195-203, 1981

3. Emmelot, P., C.J. Bos, E.L. Benedetti, and P.H. Rumke. Studies on plasma membranes I. Chemical composition and enzyme content of plasma membranes isolated from rat liver. Biochim. Biophys. Acta 90, 126-145, 1964 
4. Esmann, M., J.C. Skou, and C. Christensen. Solubilization and molecular weight determination of the $\left(\mathrm{Na}^{+}, \mathrm{K}^{+}\right)$ATPase from rectal glands of Squalus acanthias. Biochim. Biophys. Acta 154, 540-552, 1979

5. Fambrough, D.M. Studies on the $\left(\mathrm{Na}^{+}, \mathrm{K}^{+}\right)$ATPase of skeletal muscle and nerve. Cold Spring Harbor Symp. Quant. Biol. 48, 297-304, 1983

6. Fambrough D.M., and E.K. Bayne. Multiple forms of $\left(\mathrm{Na}^{+}, \mathrm{K}^{+}\right)$APTase in the chicken. J. Biol. Chem. 258, 3926-3935, 1983

7. Fleischer, B., S. Fleischer, and H. OzaWA. Isolation and characterization of Golgi membranes from bovine liver. J. Cell Biol. 43, 59-79, 1969

8. Geering, K., D.I. Meyer, M.-P. Paccolat, J.-P. Kraehenbuhl, and B.C. Rossier. Membrane insertion of $\alpha$ - and $\beta$-subunits of $\left(\mathrm{Na}^{+}, \mathrm{K}^{+}\right)$ATPase. J. Biol. Chem. 260, 5154-5160, 1985

9. Gregori, C., C. Besmond, A. Kahn, and J.-C. Dreyfus. Characterization of messenger RNA for aldolase B in adult and fetal human liver. Biochem. Biophys. Res. Commun. 104, 369-375, 1982

10. Hayashi, Y., T. Takagi, S. Maezawa, and H. Matsui. Molecular weights of $\alpha \beta$-protomeric and oligomeric units of soluble $\left(\mathrm{Na}^{+}, \mathrm{K}^{+}\right)$ATPase determined by low-angle laser light scattering after high-performance gel chromatography. Biochim. Biophys. Acta 748, 153-167, 1983

11. Hiatt, A., A.A. Mcdonough, and I.S. Edelman. Assembly of the $\left(\mathrm{Na}^{+}, \mathrm{K}^{+}\right)$-adenosine triphosphatase. J. Biol. Chem. 259, 2629-2635, 1984

12. JoRGENSEN. P.L. Isolation of $\left(\mathrm{Na}^{+}, \mathrm{K}^{+}\right)$ATPase. Methods Enzymol. 32, 277-290, 1974

13. J $\phi$ RGEnSEN. P.L. Purification and characterization of $\left(\mathrm{Na}^{+}, \mathrm{K}^{+}\right) \mathrm{ATPase}$. Biochim. Biophys. Acta 356, 36-52, 1974

14. J $\phi$ RGENSEN P.L. Sodium and potassium ion pump in kidney tubules. Physiological Reviews. 60, 864-917, 1980

15. J $\phi$ RGENSEN, P.L. Mechanism of the $\left(\mathrm{Na}^{+}, \mathrm{K}^{+}\right)$pump protein structure and conformations of the pure $\left(\mathrm{Na}^{+}, \mathrm{K}^{+}\right)$-ATPase. Biochim. Biophys. Acta 694, 27-68, 1982

16. Kashgarian, M., D. Biemesderfer, M. Caplan, and B. Forbush, III. Monoclonal antibody to $\left(\mathrm{Na}^{+}, \mathrm{K}^{+}\right)$ATPase: Immunocytochemical localization along nephron segments. Kidney International. 28, 899-913, 1985

17. KYTE, J. Molecular considerations relevant to the mechanism of active transport. Nature (Lond.) 292, 201-204, 1981

18. LAEMmLi, U.K. Cleavage of structural protein during the assembly of the head of bacteriophage T4. Nature (Lond.) 227, 680-685, 1970

19. Leskes, A., P. Siekevitz, and G.E. Palade. Differentiation of endoplasmic reticulum in hepatocytes. I. Glucose-6-phosphatase distribution in situ. J. Cell Biol. 49, 264-287, 1971

20. Lowry, O.H., H.J. Rosebrough., A.L. Farr, and R.J. Randall. Protein measurement with the folin phenol reagent. J. Biol. Chem. 193, 265-275, 1951

21. Nakao, T., T. Ohno, M. Nakao, G. Maeki, S. Tsukita, and H. Ishikawa. Monomeric and trimeric structures of active $\left(\mathrm{Na}^{+}, \mathrm{K}^{+}\right)$ATPase in $\mathrm{C}_{12} \mathrm{E}_{8}$ solution. Biochem. Biophys. Res. Commun. 113, 361-367, 1983

22. Omori, K., S. TAKemura, K. Omori, T. Mega, and Y. TAShiro. Isolation of the $\alpha$ and $\beta$ subunits of canine $\left(\mathrm{Na}^{+}, \mathrm{K}^{+}\right)$ATPase by using SDS-PAGE and lectin-Sepharose. J. Biochem. (Tokyo) 94, 1857-1866, 1983

23. PARVIn, R.A., and S. Roberts. Determination of inorganic phosphate in the presence of labile organic phosphatase. Anal. Biochem. 27, 65-72, 1969

24. Pricer, W.E. Jr, and G. Ashwell. Subcellular distribution of a mammalian hepatic-binding protein specific for asialoglycoproteins. J. Biol. Chem. 251, 7539-7544, 1976

25. Sabatini, D., D. Colman, E. Sabban, J. Sherman, T. Morimoto, G. Kreibich, and M. ADESNIK. Mechanisms for the incorporation of proteins into the plasma membrane. Cold Spring Harbor Symp. Quant. Biol. 46, 807-817, 1981

26. Schenk, D.B., and H.L. LefFert. Monoclonal antibodies to rat $\mathrm{Na}^{+}, \mathrm{K}^{+}$-ATPase block enzymatic activity. Proc. Natl. Acad. Sci. U.S.A. 80, 5281-5285, 1983

27. Sweadner, K.J., and R. C. Gilkeson. Two isozymes of the Na, K-ATPase have 
distinct antigenic determinants. J. Biol. Chem. 260, 9016-9022, 1985

28. Takemura, S., K. Omori, K. Tanaka, K. Omori, S. Matsuura, Y. Sameshima, and Y. Tashiro Quantitative immunoferritin localization of $\left(\mathrm{Na}^{+}, \mathrm{K}^{+}\right)$ATPase on canine hepatocyte cell surface. J. Cell Biol. 99, 1502-1510, 1984

29. Tamkun, M.M., and D. M. Fambrough. The $\left(\mathrm{Na}^{+}, \mathrm{K}^{+}\right)$ATPase of chick sensory neurons. Studies on biosynthesis and intracellular transport. J. Biol. Chem. 261, 1009-1019, 1986

30. Voitukaitis, J.L. Production of antisera with small doses of immunogen: multiple intradermal injections. Method Enzymol. 73, 46-52, 1981

(Received for publication, June 19, 1986) 